\title{
Knowledge Attitude and Practice about Breast Cancer among Civil Servants in Benin City, NIGERIA
}

\author{
O. C. Osime, O. Okojie, E. T. Aigbekaen and I. J. Aigbekaen \\ Department of Surgery, University of Benin Teaching Hospital, Benin City, Nigeria \\ Reprint requests to: Dr. O. C. Osime, Department of Surgery, U. B. T. H, P. M. B. 1111, Benin City, Edo State, \\ Nigeria. Email: clementosime@yahoo.com, Tel.: +2348023332674, +23452603071
}

\begin{abstract}
Background: Breast cancer is often associated with severe morbidity and mortality especially when the patients present late. A major reason why patients present late is the lack of awareness about breast cancer, its complications and the management.

Methods: The study was carried out using a structured questionnaire. A total of 400 female civil servants were enlisted in the study, but only 385 respondents completed and returned the forms.

Results: Two hundred and seventy seven (72.0\%) respondents had tertiary level of education. Sixty six (17.1\%) respondents were in the 30-34-year age group. Three hundred and twelve $(81.0 \%)$ respondents knew correctly that breast lump is usually the first symptom of presentation of breast cancer. One hundred and forty four (37.5\%) respondents knew that a positive family history of breast cancer is a risk factor, while two hundred and seventy four (71.2\%) respondents answered that cancer of one breast in a woman increases her chances of having cancer of the other breast. Three hundred and twenty one (83.4\%) respondents knew that breast cancer could spread from one breast to the other and two hundred and thirty (59.7\%) knew that breast cancer could spread to other parts of the body. One hundred and eighty three (47.5\%) respondents would visit the hospital as the first reaction if they were to detect a breast lump, while twenty three (6.0\%) respondents would ignore the lump. While three hundred and twenty seven (85.0\%) respondents have heard of breast self- examination, only one hundred $(26.0 \%)$ could correctly describe the procedure of breast self -examination. While one hundred and thirty five (35.0\%) respondents have heard of mammography, only twenty seven (7\%) respondents go for yearly mammography screening. Three hundred and seventy two (96.6\%) respondents know that mastectomy is done as part of the management of breast cancer, but only forty nine $(12.7 \%)$ respondents have heard about conservative surgery.

Conclusion: The level of awareness about breast cancer among civil servants in Benin City is low. There is the need to organize series of health education programs to enlighten the women about breast cancer. This can be done by government agencies or the non-governmental organizations. If properly executed, it may influence the attitude of women in Benin City about breast diseases and encourage early presentation to the hospital.
\end{abstract}

Key words: Breast cancer, knowledge, civil servants

Résumé

Contexte: Le cancer du sein est souvent associé à une morbidité et une mortalité sévère particulièrement lorsque les patientes consultent tard. La raison principale de cette consultation tardive est le manque de sensibilisation sur le cancer du sein, ses complications et son traitement.

Méthode: L'étude a été menée à l'aide d'un questionnaire structuré. Au total de 400 femmes 
fonctionnaires ont été enrôlées dans l'étude, mais seulement 385 complétèrent et retournèrent le questionnaire.

Résultats: Deux cent soixante dix sept (72,0\%) des participantes avaient un niveau d'éducation tertiaire. Soixante six $(17,1 \%)$ étaient de la tranche d'âge de 30 à 34 ans. Trois cent douze $(81,0 \%)$ savaient parfaitement que le nodule du sein est habituellement la première manifestation du cancer du sein. Cent quarante quatre (37,5\%) savaient qu'un antécédent familial de cancer du sein était un facteur de risque, tandis que deux cent soixante quatorze $(71,2 \%)$ répondirent qu'un cancer dans un sein chez une femme augmentait le risque d'avoir un cancer dans l'autre sein. Deux cent soixante et onze $(83,4 \%)$ savaient que le cancer du sein pouvait s'étendre d'un sein à l'autre et deux cent trente $(59,7 \%)$ savaient que le cancer pouvait s'étendre à d'autres parties du corps. Cent quatre vingt trois $(47,5 \%)$ seraient prêtes à consulter à titre de première réaction si elles étaient amenées à constater un nodule du sein, tandis que vingt-trois $(6,0 \%)$ I'ignoreraient. Alors que trois cent vingt-sept $(85,0 \%)$ avaient entendu parler de l'auto palpation du sein, seulement cent $(26,0 \%)$ pouvaient correctement décrire cette procédure. Pendant que cent quarante cinq $(35,0 \%)$ avaient entendu parler de la mammographie, seulement 27 (7\%) procèdent à une mammographie annuelle. Trois cent soixante douze $(96,6 \%)$ savent que la mammographie est pratiquée comme un élément de la prise en charge du cancer du sein, mais seulement quarante neuf $(12,7 \%)$ ont entendu parler de chirurgie conservatrice.

Conclusion: Le niveau de connaissance sur le cancer du sein parmi les fonctionnaires de Benin City est bas. Il y a nécessité d'organiser des séries de programmes d'éducation pour éclairer les femmes au sujet du cancer du sein. Cela peut se faire par des agences gouvernementales ou des organisations non gouvernementales. Proprement exécuté, cela devrait influencer l'attitude des femmes de Benin City a propos des maladies du sein et encourager les consultations précoces.

Mots clés: Cancer du sein, connaissance, fonctionnaires

\section{Introduction}

Breast cancer is the commonest malignant condition afflicting females all over the world. ${ }^{1-3}$ The mortality and morbidity associated with the condition is quite high and rather disturbing. Over the years, various attempts have been made at either preventing breast cancer or managing breast cancer when it does occur.

The results of prevention of breast cancer or breast cancer cure have not been very encouraging more so in the developing countries. One major determinant whether a cure for breast cancer will be possible or not is the stage at which the patient presents. For those that present early to the right persons, one can aim at a cure, while those that present late are unlikely to have a cure. ${ }^{4}$

Several factors determine the stage at which patients with breast cancer present to the hospital. Some of such factors include educational status, financial capability, occupation, location, presence of health care facilities, etc. However, a common denominator of these factors is the level of awareness and attitude toward breast cancer. For those patients that are aware about the disease and have the right attitude toward it, there is an increased chance that they will present early for treatment, while the contrary will be the case for those patients who may not even be aware of breast cancer and also have wrong attitude toward the disease.

The purpose of this study therefore, is to evaluate the knowledge, attitude and practice toward breast cancer among civil servants in Benin City and to compare the findings with related studies done in other places. It is also hoped that the information obtained will help in designing a proper health education scheme regarding breast cancer.

\section{Materials and Methods}

The study was carried out by means of structured questionnaire. The female staff of the Ministry of Health, Ministry of Education and three secondary schools (all in Benin City, Nigeria), were enlisted in the study. The researchers explained the objective of the study to the respondents and their oral consent was subsequently obtained. They were also educated on how to complete the questionnaires. A total of 400 persons were given the forms, but only 385 persons completed and returned the forms and it was these 385 respondents that were included in the study. The completed questionnaires were retrieved and analyzed using simple tables.

\section{A brief description of breast self-examination}

Breast Self-examination usually involves inspection and palpation of the breast and should be done at least once a month at about the 7th day after the commencement of menstrual period.

\section{Inspection}

The clothes and bra are removed and then stand in the front of a mirror with the arms by the sides. While facing forward and turning from side to side, 
look for puckering, dimpling or changes in size, shape or symmetry. Check to see if the nipples are turned in (inverted). The breasts are inspected with the arms in two other positions - hands on the hips and hands raised over the head with the palms pressed together.

\section{Palpation (manual part)}

The manual part is done either in the shower or while lying down (preferably while lying down) and the aim is to identify lumps or other abnormalities when they are present. Visualize the breast as the face of a clock. While lying down, the left hand is placed behind the head and the left breast is examined with the right hand. The right hand is placed at $120^{\prime}$ clock at the very top of the breast.Then the pads of the three middle fingers are pressed firmly on the breast in slight circular massaging motion. The hand is then moved to $10^{\prime}$ clock, then $20^{\prime}$ clock and this is continued until one gets to the 12 O'clock position again. The same pattern is repeated, but now in smaller circles toward the nipple. The tissue under the nipple is checked and discharge is also looked for by gently expressing the nipple. The tissue under the arm pit is also checked. After examining the left breast, you then place your right hand behind the head and repeat the examination on the right breast using the right hand.

Any lumps or abnormal findings detected during the examination should be reported to the physician.

\section{Results}

A total of 385 women were included in the study. Two hundred and seventy seven $(72.0 \%)$ respondents had tertiary education and the mean age of respondents was $38 \pm 9.4$ years (Tables 1 and 2 ) . Three hundred and twelve $(81.0 \%)$ respondents know that breast lump is usually the first symptom of breast cancer to be noticed while one hundred and forty six $(38.0 \%)$ respondents think that pain is the principal symptom in patients with breast cancer (Table 3).

One hundred and forty four (37.4\%) respondents knew that family history of breast cancer is a risk factor for carcinoma of the breast, while two hundred and seventy four (71.2\%) answered that patient with carcinoma of one breast has a risk of having carcinoma of the other breast, (Table 4). Table 5 shows the knowledge about spread of breast cancer with one hundred and thirty seven (35.7\%) respondents having the impression that breast cancer does not spread to other parts of the body.

One hundred and eighty three (47.5\%) respondents will visit the hospital as the first response if they detected a breast lump, ninety one (23.6\%) respondents will use herbal medications and twenty three $(6.0 \%)$ respondents will simply ignore the condition. (Table 6).

Three hundred and twenty seven (85.0\%) respondents have heard about breast selfexamination, however, only one hundred (26.0\%) respondents could correctly describe the procedure of breast self- examination (Table 7). While one hundred and thirty five $(35.0 \%)$ respondents have heard about mammography, only twenty seven (7.0\%) respondents go for yearly mammography screening. (Table 8). Three hundred and seventy two (96.6\%) respondents knew that mastectomy is a major treatment modality but only forty nine respondents (12.7\%) have heard about conservative surgery for management of early breast cancer (Table 9).

Table 1. Educational status of the respondents

\begin{tabular}{lll}
\hline Educational level & No. & $\%$ \\
\hline Primary & 31 & 8 \\
Secondary & 77 & 20 \\
Tertiary & 277 & 72 \\
\hline Total & 385 & 100 \\
\hline
\end{tabular}

Table 2. Age distribution of respondents

\begin{tabular}{ll}
\hline Age (years) & No. (\%) \\
\hline$<20$ & $6(1.6)$ \\
$20-24$ & $29(7.5)$ \\
$25-29$ & $42(10.9)$ \\
$30-34$ & $66(17.1)$ \\
$35-39$ & $58(15.1)$ \\
$40-44$ & $61(15.8)$ \\
$45-49$ & $64(16.6)$ \\
$\geq 50$ & $59(15.3)$ \\
\hline Total & $385(100)$ \\
\hline Mean age $=38 \pm 9.4$ years &
\end{tabular}

Table 3. Knowledge about the main presenting symptoms of breast cancer

\begin{tabular}{ll}
\hline $\begin{array}{l}\text { Symptoms of breast cancer as } \\
\text { indicated by respondents }\end{array}$ & No. (\%) \\
\hline Breast Lump & $312(81.0)$ \\
Swelling and pain in the breasts & $146(38.0)$ \\
When the breast lump ulcerates & $99(25.7)$ \\
Very huge breast mass & $66(17.7)$ \\
No response & $40(10.4)$ \\
\hline There were multiple responses &
\end{tabular}


Table 4. Knowledge about the risk factors for breast cancer

\begin{tabular}{lll}
\hline Risk factors & $\begin{array}{l}\text { No. of respondents that answered Yes } \\
\text { (\%) }\end{array}$ & $\begin{array}{l}\text { No. of respondents that } \\
\text { answered No (\%) }\end{array}$ \\
\hline Positive family history & $144(37.4)$ & $241(62.2)$ \\
Women that do not breast feed & $92(23.9)$ & $293(76.1)$ \\
Having had cancer of one breast & $274(71.2)$ & $111(28.8)$ \\
Obesity & $55(14.3)$ & $330(85.7)$ \\
Increasing age & $151(39.2)$ & $234(60.8)$ \\
Early onset of menarche & $52(13.5)$ & $333(86.5)$ \\
Late onset of menopause & $58(15.1)$ & $327(84.9)$ \\
Use of oral contraceptive pills & $52(13.5)$ & $333(86.5)$ \\
Physical inactivity & $89(23.1)$ & $296(76.9)$ \\
High fat diet & $177(46.0)$ & $208(54.0)$ \\
Alcohol ingestion & $119(29.9)$ & $266(69.1)$ \\
Smoking & $250(64.9)$ & $135(35.1)$ \\
Radiation exposure & $27(7.0)$ & $358(93.0)$ \\
\hline
\end{tabular}

Table 5. Knowledge about spread of breast cancer

\begin{tabular}{lll}
\hline $\begin{array}{l}\text { What they know } \\
\text { about spread of } \\
\text { breast cancer }\end{array}$ & No. (\%) & \\
\hline & Yes & No \\
\cline { 2 - 3 } $\begin{array}{l}\text { Spread from one } \\
\text { breast to the other }\end{array}$ & $321(83.4)$ & $64(16.6)$ \\
$\begin{array}{l}\text { Spread to other parts } \\
\text { of the body }\end{array}$ & $230(59.7)$ & 155 \\
& & (40.3) \\
\hline
\end{tabular}

Table 6. What respondents would do first if they noticed a breast lump

\begin{tabular}{ll}
\hline What they will do & No. (\%) \\
\hline Visit the hospital & $183(47.5)$ \\
Use herbal medications & $91(23.6)$ \\
Pray about it & $78(20.3)$ \\
Ignore the condition & $23(6)$ \\
No response & $10(2.6)$ \\
\hline
\end{tabular}

Table 7. Knowledge about breast selfexamination (BSE)

\begin{tabular}{lll}
\hline Information on BSE & No. (\%) & \\
\hline & Yes & No \\
\cline { 2 - 3 } Heard of BSE & $327(85.0)$ & $58(15.0)$ \\
Practise sbe & $264(68.5)$ & $121(31.5)$ \\
Practise sbe monthly & $135(35.0)$ & $250(65.0)$ \\
Correctly described & $100(26.0)$ & $285(74.0)$ \\
the procedure & &
\end{tabular}

\section{Discussion}

In the present study, two hundred and seventy seven (72.0\%) of the civil servants interviewed had tertiary education and it was therefore easy to communicate with them. The ages of the respondents ranged from 18 to 59 years with a mean of $38 \pm 9.4$ years. Three hundred and twelve (81.0\%) of the respondents answered correctly that the commonest symptom of breast cancer is a breast lump, even though sixty six (17.7\%) respondents believed that the lump expected to be malignant is usually of large size and often times visible. In a similar study carried out among female school teachers in Lagos, only $53.3 \%$ knew correctly that a lump was the commonest recognized symptom of breast cancer. ${ }^{5}$ In another study among a cross section of Nigerian population, only $33 \%$ of the population studied knew that a breast lump could be a warning sign of breast cancer. ${ }^{6}$

Table 8. Knowledge about the use of mammography as a screening tool

\begin{tabular}{lll}
\hline Use of mammography & Yes & No \\
\hline Have heard about & 135 & $250(65.0)$ \\
mammography & $(35.0)$ & \\
$\begin{array}{l}\text { Go for yearly } \\
\text { mammography screening }\end{array}$ & $27(7.0)$ & $358(93.0)$ \\
\hline
\end{tabular}

Table 9. Knowledge about the variuos methods of treatment of breast cancer

\begin{tabular}{lll}
\hline Treatment modality & Yes & No \\
\hline Mastectomy & $372(96.6)$ & $13(3.4)$ \\
Conservative surgery & $49(12.7)$ & $336(87.3)$ \\
Chemotherapy & $161(41.8)$ & $224(58.2)$ \\
Radiotherapy & $152(38.5)$ & $233(60.5)$ \\
\hline
\end{tabular}


In the present study, ninety nine (25.7\%) respondents believe that it is only when the breast lump begins to ulcerate that the possibility of breast cancer is considered while one hundred and forty six (38.0\%) respondents believe that it is only when a breast lump is painful that it is malignant. Similarly, in the study carried out by Haji-Mahmoodi et al, ${ }^{7}$ only $27 \%$ knew that pain is not a cardinal feature of breast cancer. Other studies have also reported similar findings. ${ }^{8,9}$ These wrong information or assumptions about breast lumps may account for some of the reasons why some of our patients present late to hospital. ${ }^{8-11}$ In the study on why patients with breast cancer present late for management, several studies found that majority of the patients have a wrong perception of malignant diseases of the breast, particularly the early symptoms of breast cancer. ${ }^{1-}$ $3,12,13$

In terms of associated risk factors for breast cancer, $71.2 \%$ of the respondents knew that breast cancer affecting one breast is risk factor for developing breast cancer of the other breast. Ninety two $(23.9 \%)$ respondents knew that a positive family history of breast cancer is a risk factor, while only $14.3 \%$ knew that obesity is also an implicated risk factor. Most of the respondents interviewed in this study did not know of the association between breast cancer and early menarche, late menopause, use of oral contraceptives, increasing age of patient, women that do not breastfeed and age at first child birth. However, some studies have shown that the incidence of breast cancer is said to be slightly higher in persons that have first degree relatives with a history of breast cancer, persons that have early menarche and late menopause and those that use oral contraceptives, persons do not breast feed and those women having their first birth after age 35 or nulliparous women. The incidence is also increased with increasing age of the patient, smoking, obesity, physical inactivity, radiation exposure, intake of alcohol and high fat diet. $5,8,12$ Thus further health education on associated risk factors and protective factors is desirable. This may influence the attitudes, practices and lifestyle of our patient positively. In a study done by Adebamawo et al, ${ }^{12}$ it was observed that patients with positive family history tend to present early for management.

In the present study, $83.6 \%$ of the respondents knew that breast cancer could spread to the contralateral breast, while $12.2 \%$ believe that it does not spread to the contralateral breast. In addition, $35.7 \%$ of the respondents believe that breast cancer is usually limited to the breasts, and that it does not spread to other parts of the body, while $59.7 \%$ knew correctly that breast cancer can spread to other parts of the body. Other studies on the knowledge about breast cancer have reported similar findings. ${ }^{14,15}$

The attitude of some of our respondents about breast cancer was found to be wrong. When asked what they will do if they were diagnosed to have breast cancer, about $20.3 \% \%$ claimed that they will pray about it; $23.6 \%$ prefer to use herbal medications and another $6 \%$ of the respondents claim that they will simply ignore the condition. One hundred and eighty three $(47.5 \%)$ respondents however claimed that they will go to the hospital for treatment. Use of alternative methods of treatment as the first line of management is common in most developing countries and accounts for one of the reasons why most of our patients present late to the hospital. ${ }^{6,8,9,13}$ This attitude among our patients should be discouraged and the benefits of early presentation especially with respect to breast cancer emphasized.

Another major factor why we experience late presentation of breast cancer is that most women do not carry out breast self- examination and they do not also take advantage of the screening role of mammography. It is either they have never heard of breast self- examination or they do not know how to carry it out. ${ }^{14-16}$ It is also possible that they can carry out breast self-examination, but the motivation to carry it out is absent. In the present study, $15 \%$ of the respondents have never heard of breast selfexamination, while $85 \%$ have heard of breast selfexamination, but only $68.5 \%$ of such respondents carry out breast self- examination. Among those that carry out breast self-examination, only $35 \%$ carried it out monthly, while $65 \%$ do not carry out monthly breast self-examination. it was discovered that only $26 \%$ could correctly describe the procedure. Several studies on breast self-examination have reported similar findings. ${ }^{16-19}$ This may be as a result of poor health education in our society. In a study done among secondary school teachers, only about $25 \%$ had adequate knowledge of breast selfexamination. ${ }^{18}$ The implication therefore is that $75 \%$ of such a group of teachers cannot impact on their students the importance of breast self-examination. Freeman et $\mathrm{al}^{20}$ also emphasized the need for adolescents to be properly taught the routine of breast self-examination as this will greatly influence their practice as they grow older. A related study showed that some nurses do not appreciate the importance of breast self-examination and the need for clinical breast examination. ${ }^{21}$ Similarly, Ajayi et $\mathrm{al}^{22}$ found that only about $74.6 \%$ of family physicians interviewed had a program for clinical breast examination for their patients. Other studies have reported similar findings. ${ }^{16-20}$ The implication of all of these is that there is the need for proper orientation about breast cancer among the various caregivers which in turn is expected to boost the level of awareness in the society.

The knowledge of the use of mammography as a screening tool for early detection of breast cancer was found to be poor among our respondents. Only $35 \%$ of the respondents have heard about screening 
mammography while only $7 \%$ go for yearly mammography screening. A similar finding was reported by Okobia et al. ${ }^{23}$ Health education about the benefits of mammography screening should be encouraged. Regarding treatment, $96.6 \%$ of the respondents know that mastectomy is a method of treatment of breast cancer, but only $12.7 \%$ have heard of the use of conservative surgery for the management of early breast cancer. Regarding chemotherapy and radiotherapy, only $41.8 \%$ and $39.5 \%$ respectively have heard of the procedure. Similar findings have been reported by other studies. $^{8,23}$ Thus while most persons know about mastectomy, only few know about the other treatment modalities. Health education along this line will also be a useful tool in influencing the attitude and practices of our patients about breast cancer. The use of conservative surgery for management of early breast cancer should be emphasized as this can a long way in encouraging patients to present early.

In conclusion, the level of awareness about breast cancer among civil servants in this setting is low. Health education at all levels needs to be encouraged. If adequate level of awareness is achieved, it is hoped that patients with breast cancer would present early.

\section{References}

1. Ikpatt OF, Kuopoo I, Ndoma-Egbe R, Collen Y. Breast cancer in Nigeria and Finland: epidemiological, clinical and histological comparison. Anticancer Res. 2002;22:3005-3012.

2. Okobia MN, Osime U. Clinicopathological study of carcinoma of the breast in Benin City. Afr J Reprod Health. 2001;5:56-62.

3. Ohanaka CE, Ofoegbu RO. The pattern of surgical cancers in Nigeria: the Benin experience. Trop Doct. 2002;32:38-39.

4. Forbes JF. Surgery of early breast cancer. Curr Opin Oncol. 1993;5:966-975.

5. Odusanya OO. Breast cancer: knowledge, attitudes and practices of female school teachers in Lagos, Nigeria. Breast J. 2001;7:171-175.

6. Uche EE. Cancer awareness among a Nigeria population. Trop Doct. 1999;29:39-40.

7. Haji-Mahmoodi $M$, Montazeri A, Jarvandi $S$, Ebrahim M, Haghighat S, Harirchi I. Breast self examination: knowledge, attitudes and practices among female health care workers in Tehan, Iran. Breast J. 2002;8:222-225.
8. Adebamowo CA, Ajayi OO. Breast cancer in Nigeria. West Afr J Med. 2000;19:179-191.

9. Visvanathan R. Breast cancer in Nigeria women. Br J Surg. 1993;80:126-129.

10. Grunfield EA, Ramirez AJ, Hunter MS, Richards MA. Women's knowledge and beliefs regarding breast cancer. Br J Cancer. 2002;86:1878-8.

11. Katz RC, Meyers K, Walls J. Cancer awareness and self-examination practices in young man and women. J Behar Med. 1995;18:377-384.

12. Adebamowo CA, Adekunle OO. Case controlled study of the epidemiological risk factors of breast cancer in Nigeria. Br J Surg. 1999;86:665668.

13. Salleh MR. The consultation of traditional healers by Malay patients. Med J Malaysia. 1989;44:313.

14. Adderly-Kelly B, Green PM. Breast cancer education, self efficacy and screening in older African American women. J Natl Black Nurses Assoc. 1997;9:45-57.

15. Rutledge DN, Barserick A, Knobf MT, Book-binder M. Breast cancer detection: knowledge, attitude and behaviour of women from Penssylvania. Oncol Nurs Forum. 2001;28:1032-1040.

16. Abdel-Fattah M, Zaki A, Bassili A, Shazly M, Tognoni $G$. Breast self examination practice and its impact on breast cancer diagnosis in Alexandria, Egypt. East Mediterr Health J. 2000;6:34-40.

17. Hassan I, Onakek EE, Mabogunje AO. Breast cancer in Nigeria. J $\mathrm{R}$ Coll Surg Edinb. 1992;37:159-161.

18. Odusanya OO, Tayo OO. Breast cancer knowledge, attitudes and practice among nurses in Lagos, Nigeria. Acta Oncol. 2001;40:844-848.

19. Drakshyani Devi K, Venkata Ramaiah P. Teachers knowledge as practice of breast self examination. Indian J Med Sci. 1994;48:284-287.

20. Hall LS. Breast self examination: use of a visual reminder to increase practice. AAOHN J. 1992;40:186-192.

21. Freeman AG, Scott C, Waxman A, Arcona S. What do adolescent females know about breast cancer and prevention? Pediatr Adolesc Gynecol. 2002;13:96-98.

22. Ajayi IO, Adewole IF. Breast and cervical cancer screening activities among family physicians in Nigeria. Afr J Med Sci. 2002;31:305-309.

23. Okobia MN, Bunker $\mathrm{CH}$, Okonofua F, Osime U. Knowledge, attitude and practice of Nigerian women towards breast cancer: A cross-sectional study. World J Surg Oncol. 2006;4:11-16. 